\title{
The amount of liquid patients use to take tablets or capsules
}

\author{
Received (first version): $\quad$ 12-Mar-2009 $\quad$ Accepted: 5-Aug-2009
}

\begin{abstract}
${ }^{*}$
The correct use of pharmaceutical drugs supports therapy success and reduces the number of adverse side effects. One relevant aspect of use concerns the amount of liquid consumed when taking compact and shaped medicines.

Objective: The aim of this study was to investigate the volume of liquid used by patients when administering their medication.

Methods: Every patient who bought tablets or capsules from the study leader in a pharmacy in Jena (Germany), and wanted to take their medicine immediately, received a glass containing $150 \mathrm{ml}$ of water. The volume of water consumed by the patients was measured after they took their medication.

Results: 21 out of the 136 participants (15.4\%) used only up to $60 \mathrm{ml}$ of liquid to take their tablets or capsules. Significant influences of demographic aspects, such as age or gender, on the volume of used liquid were not found. However, an increase in tablet or capsule size led to a significant increase in the volume of swallowed liquid.

Conclusion: Patients need to be better informed about drinking a sufficient amount of liquid when taking tablets or capsules orally. Therefore, it is important that every package insert of compact and shaped medicines contains this information. In addition, medical and pharmaceutical experts should also provide this advice to their patients.
\end{abstract}

Keywords: Tablets. Capsules. Counseling. Drug Labeling. Germany.

\section{CANTIDAD DE LÍQUIDO QUE USAN LOS PACIENTES PARA TOMAR LAS TABLETAS O CAPSULAS}

\section{RESUMEN}

El uso correcto de los medicamentos soporta el éxito terapéutico y reduce el número de efectos adversos. Un aspecto relevante del uso se refiere a la cantidad de líquido consumida cuando toman formas orales sólidas.

Objetivo: El objetivo de este estudio fue investigar el volumen de líquido utilizado por los pacientes cuando utilizan su medicación.

Métodos: Cada paciente que compraba tabletas o capsulas en una farmacia en Jena (Alemania) y quería tomar inmediatamente la medicación, recibió un vaso conteniendo $150 \mathrm{ml}$ de agua. El volumen de agua consumido por los pacientes se medía después de que tomasen la medicación.

Resultados: 21 de los 136 participantes $(15,4 \%)$ utilizaron solo hasta $60 \mathrm{ml}$ de líquido para tomar sus tabletas o cápsulas. No se encontraron influencias significativas de aspectos demográficos, tales como edad o género, en cuanto al volumen de líquido utilizado. Sin embargo, un aumento en el tamaño de la cápsula o la tableta llevaba a un aumento significativo del volumen de líquido tragado.

Conclusión: Los pacientes necesitan estar mejor informados sobre beber una cantidad suficiente de agua cuando toman oralmente cápsulas o tabletas. Por tanto, es importante que cada prospecto de formas orales sólidas contenga esta información. Además, médicos y farmacéuticos también deberían proporcionar este consejo a los pacientes.

Palabras clave: Tabletas. Capsulas. Consejo. Prospectos. Alemania.

\section{INTRODUCTION}

The correct use of medicines is very important to assure high success in treatments and to avoid adverse drug reactions. In this context, patients should show a high rate of compliance when administering their medications: use the correct amount of medicine at the right time and over the appropriate duration. ${ }^{1,2}$ In addition to compliance, further considerations should also be taken into account:

\footnotetext{
*Joerg FUCHS. PAINT-Consult, Jena; and Department for Drug Regulatory Affairs at the Institute of Pharmacy, University of Bonn (Germany)
}

- Can the patient use the medicine without assistance, such as inhalers or injectors? 
- Can the patient measure the correct dose?

- Do the patients understand the dosage instructions or other required information for safe use?

- Is the patient able to split the tablet correctly? $?^{3-6}$

Another aspect, which is not so frequently reported, concerns the amount of liquid used to swallow orally administered, compact and shaped pharmaceuticals, such as tablets and capsules. For example, Gallo et al. reported that successful esophagus passages of tablets are significantly influenced by the body position of the patient and the volume of liquid consumed. Taking a $12.5 \mathrm{~mm}$ barium sulphate tablet in a supine position resulted in an overall rate of successful esophagus passage in only $17.0 \%$ of the 20 test participants. However, a $45^{\circ}$ upright position of the upper body increased the success rate to $66.5 \%$ and a vertical position to $69.7 \%$. A quick tablet transport from the mouth to the stomach in a supine position was achieved according to the consumed liquid as follows: no liquid $=9.1 \%, \quad 15 \mathrm{ml}=38.7 \%, \quad 30 \mathrm{ml}=55.8 \%$, $60 \mathrm{ml}=70.0 \%$ and $100 \mathrm{ml}=81.6 \%$. Capsules or tablets which stick to the esophagus cannot be easily removed or dislodged by drinking further liquid or eating. Therefore, the authors of the above study recommended that when taking orally administered tablets people should drink a minimum of $60 \mathrm{ml}$ of liquid and position the upper body at a minimum of $45^{\circ}$ to achieve a high passage rate of tablets or capsules. ${ }^{7}$ Other authors have published similar findings. ${ }^{8}$

These recommendations are extremely important because tablets or capsules that remain in the esophagus inhibit the quick effects of the medicine. Furthermore, there are many known active substances which severely harm the esophagus if they release in this organ. Bisphosphonates, tetracyclines and NSAIDs are some examples. ${ }^{9}$

However, information relating to the amount of liquid needed for successful esophagus passage was given in only $20.5 \%$ of the investigated 68 package inserts available on the German medicine market in 2000. Recommendations that tablets and capsules should be taken in an upright position were missing in all cases. $^{10}$ Unpublished research, recently completed by our research group, found slightly better results. Of 271 randomly selected package inserts from the German medicine market in the year $2005,31.6 \%$ contained information regarding the amount of liquid that should be consumed when taking the medication. However, again, not a single package insert designed for orally taken, compact and shaped medicines provided advice that the product should be taken in an upright upper body position.

Therefore, the following study was initiated to investigate:

- how much liquid patients usually drink when they take medications such as capsules or tablets
- which variables influence the volume of consumed liquid, for example gender and age.

\section{METHODS}

The survey was carried out between February and December 2005 in a pharmacy in Jena (Germany). All patients who were sold, by the study leader (pharmacist), shaped and orally administered medicines and who requested to take their medication immediately were included in this study. Each participant was given a glass containing $150 \mathrm{ml}$ of water to swallow their medicine. After the use of the prescribed or OTC medicines, the pharmacist measured, as a predefined parameter, the volume of water consumed using a measuring cylinder. In addition, each participant was observed regarding how he or she swallowed their medicine.

Furthermore, the identification code, a unique seven-digit number given to each medicine available on the German market, of each administered medicine was collected. These codes allowed for the following data to be gathered which furthered the investigation

- pharmaceutical form

- weight of the tablets and capsules

- volume of the tablets and capsules (without consideration of curves and notches), calculated by using the:

- length, breadth and height for oblong tablets

- diameter and height for round tablets

- length and diameter for capsules

The data were collected from the Gelbe Liste [yellow list] ${ }^{11}$, the medicines' summary of products characteristics and directly from the pharmaceutical companies.

All collected data were coded and inserted into a table using the SPSS statistical program via double data input checking. Averages of the consumed volume of water and if breaks were taken when swallowing the medicine were calculated for the total number of participants and different groups. Significant influences of demographic data and medicine forms on the volume of consumed liquid were checked using first the Kruskal-Wallis test as a global test and in a second step, the U-test after Mann and Whitney. In the case that significant influences occurred, the Spearman correlation coefficient was conducted.

\section{RESULTS}

136 patients with an average age of 55 years were included in this study, according to the criteria stated in the method section (minimum: 15 years of age, maximum: 83 years of age). At the time of the survey, $14.7 \%$ of the participants $(n=20)$ were between the ages of 15 and $29,36.0 \%$ were between the ages of 30 and $59(n=49)$ and the remaining $49.3 \%$ were 60 years old and over $(n=67)$. Two thirds of the participants were female 
$(65.4 \%)$, and the majority of participants lived in Jena $(81.0 \%)$.

$55.1 \%$ of the patients $(\mathrm{n}=75)$ were recruited during colder seasons - February to April and October to December. The remaining group participated between May and September 2005. Most of the administered medicines were antibiotics (58.1\%, $\mathrm{n}=79$ ). $25.7 \%$ were different types of analgesics $(n=35)$, and the remaining were medicines such as antihypertensives, antiviral drugs or proton pump inhibitors.

The patients took their medicines with an average of $115 \mathrm{ml}$ of water, which was $76.6 \%$ of the provided amount of liquid. However, before the pharmacist was able to provide a glass of water, one participant swallowed his tablet without any liquid. According to the consumed amount of water, the participants can be classified into three groups:

- 0 to $60 \mathrm{ml}: \mathrm{n}=21$ participants $(15.4 \%)$,

- 61 to $100 \mathrm{ml:} \mathrm{n}=28$ participants $(20.6 \%)$

- 101 to $150 \mathrm{ml}: \mathrm{n}=87$ participants $(64.0 \%)$.

14 of the 21 people who used 0 to $60 \mathrm{ml}$ of water were female and almost half were 60 years of age or older $(n=11)$. However, considering the larger percentages of women and elderly people that participated in this study, neither patient group was affected more than the other by insufficient liquid use when taking tablets or capsules.

Almost half of the 136 participants $(n=70)$ drank the entire provided liquid (minimum consumed volume: $145 \mathrm{ml})$. In addition, almost half of the people swallowed their medicines with water without taking a break (42.2\%), while the others stopped repeatedly. Table 1 shows the volume of water used by all participants, itemized by age group and participants' gender. It also illustrates less of a difference between the groups, as stated above. Even when not significant, young men swallowed their medicine, on average, with the highest volume of water and young women with the lowest.

In the cold season, slightly more water was consumed (average: $119 \mathrm{ml} ; \mathrm{n}=75$ ) than in warmer months (average: $109 \mathrm{ml} ; \mathrm{n}=61$ ). However, the differences were not significant.

In 135 cases of the 136 participants, data relating to the pharmaceutical form were available. Participants taking uncoated tablets $(n=36)$ swallowed on average of $107.7 \mathrm{ml}$ water. They drank on average of $118.7 \mathrm{ml}$ liquid when using coated tablets $(n=81)$ and $114.8 \mathrm{ml}$ when swallowing capsules $(n=18)$. Significant influences caused by the pharmaceutical form were not found.

The required medicine dimensions were available in 132 cases to calculate the volume of the tablets or capsules. Significant influences of the medicines' volume on the swallowed volume of water was found (Spearman's correlation coefficient: 0.188; $\mathrm{p}=0.031$ ) (Figure 1). Participants whose medicine had a volume of up to $500 \mathrm{~mm}^{3}(\mathrm{n}=67)$ used on average of $107.7 \mathrm{ml}$ water. Most of the uncoated tablets $(n=22)$ and half of the capsules $(n=9)$ were in this low volume group, which helps to explain why people who took these medicines used less liquid to swallow their medicines.

Table 1. Volume of water used to swallow compact, shaped and orally applied medicines, such as tablets or capsules, itemized by age, group and gender ( $n=136$ participants)

\begin{tabular}{|c|c|c|c|c|c|}
\hline & \multicolumn{4}{|c|}{ Volume of water (average) used to take medicines itemized regarding age } \\
\hline & & to 29 years & 30 to 59 years & 60 years and over & total \\
\hline \multirow{3}{*}{$\begin{array}{l}\text { Volume of water (average) } \\
\text { used to take medicines } \\
\text { itemized regarding gender }\end{array}$} & female & $\begin{array}{l}107 \mathrm{ml} \\
(\mathrm{n}=14)\end{array}$ & $\begin{array}{l}118 \mathrm{ml} \\
(\mathrm{n}=31)\end{array}$ & $\begin{array}{l}115 \mathrm{ml} \\
(\mathrm{n}=44)\end{array}$ & $\begin{array}{l}115 \mathrm{ml} \\
(\mathrm{n}=89)\end{array}$ \\
\hline & male & $\begin{array}{l}150 \mathrm{ml} \\
(\mathrm{n}=6)\end{array}$ & $\begin{array}{l}109 \mathrm{ml} \\
(\mathrm{n}=18)\end{array}$ & $\begin{array}{l}109 \mathrm{ml} \\
(\mathrm{n}=23)\end{array}$ & $\begin{array}{l}114 \mathrm{ml} \\
(\mathrm{n}=47)\end{array}$ \\
\hline & total & $\begin{array}{l}120 \mathrm{ml} \\
(\mathrm{n}=20)\end{array}$ & $\begin{array}{l}115 \mathrm{ml} \\
(\mathrm{n}=49)\end{array}$ & $\begin{array}{l}113 \mathrm{ml} \\
(\mathrm{n}=67)\end{array}$ & $\begin{array}{c}115 \mathrm{ml} \\
(\mathrm{n}=136)\end{array}$ \\
\hline
\end{tabular}

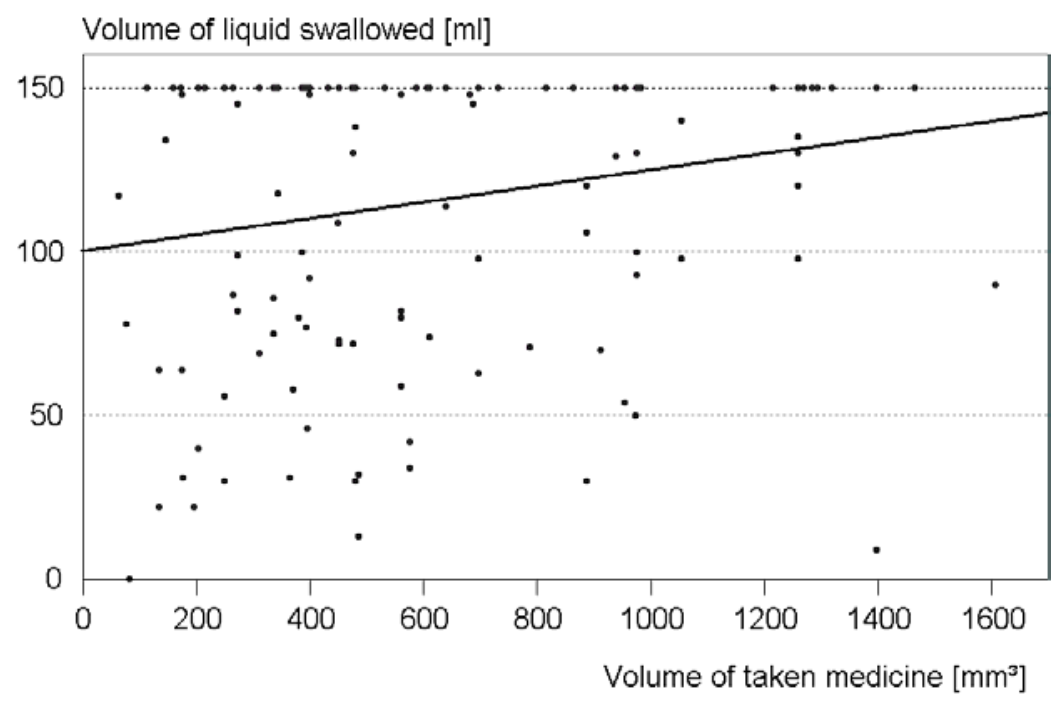

Figure 1. Relationship between the volume of medicines and the volume of water used to swallow shaped and orally applied medicines, such as tablets or capsules ( $n=132$ participants) 
Tablets or capsules with a volume of $500 \mathrm{~mm}^{3}$ to $1000 \mathrm{~mm}^{3}(\mathrm{n}=47)$ were swallowed on average with $120.0 \mathrm{ml}$ of liquid. The medicines with a volume of over $1000 \mathrm{~mm}^{3}(\mathrm{n}=18)$ were swallowed on average with $128.9 \mathrm{ml}$ of liquid.

Insignificant influence was found concerning the medicines' weight on the swallowed volume of water (Spearman's correlation coefficient: 0.160 , $\mathrm{p}=0.067$ ). People who took medicines up to $500 \mathrm{mg}$ per tablet or capsule swallowed these with the lowest amount of liquid (average: $108.7 \mathrm{ml}$ ). $122.0 \mathrm{ml}$ (average) of liquid was used when tablet or capsule weights were over 500 up to $1000 \mathrm{mg}$. Heavier tablets or capsules were taken also with an average of $122.0 \mathrm{ml}$ of liquid.

\section{DISCUSSION}

Almost every sixth person in this study swallowed tablets or capsules with too little liquid. These patients are at a higher risk of oesophagus diseases when taking certain medicines orally, such as bisphosphonates or NSAIDs. ${ }^{7,9}$ Furthermore, the percentage of people who drink too little liquid could even be higher because, in their regular environment, patients would not necessarily receive a pre-measured liquid volume of $150 \mathrm{ml}$, as in this study.

On the other hand, people could drink more water when taking their medication because they would have an unlimited amount in their own homes. Furthermore, the participants of this study could be behaving more exemplary when taking their medicine in front of a pharmacist, as compared to how they would behave privately.

Considering that the tablet size of $12.5 \mathrm{~mm}$ (diameter) used in the study of Gallo et al. ${ }^{7}$, which was larger than the average of $9.7 \mathrm{~mm}(\mathrm{~min}: 7 \mathrm{~mm}$; $\max : 16 \mathrm{~mm} ; \mathrm{n}=20$ ) of round tablets investigated in this survey, a lower volume of liquid could be considered sufficient for smaller tablets. However, oblong tablets, which were used frequently in this study and were often twice to three times larger in size than the tablet in the Gallo et al. study, could require higher volumes of liquid to successfully swallow. In addition, not only the shape of the medicine, round or oblong, but also its coatings could influence the amount of liquid required to easily swallow tablets and capsules.

One reason that some people swallow oral, compact and shaped medicines with too little liquid is because they are unaware of the possible problems associated with this behavior. Another explanation is that they drink insufficient amount of liquids as a consequence of an existing disease, such as incontinence. Significant influences by age, gender or other demographic aspects on the volume of used liquid were not found.

However, the volume of swallowed liquid was significantly influenced by the size of the medicine. This influence was higher, in comparison, to the weight of the tablets or capsules. One possible explanation for these findings could be that people visually estimate the size of the medicine which then influences the amount of liquid they consumed: when the size of the tablet or capsule increases, the amount of swallowed liquid also slightly increases.

Regardless of the variables that influence the amount of liquid a person drinks when taking their medicines, patients need to be better informed about the importance of taking tablets and capsules with a sufficient amount of liquid. This could be achieved by including in every package insert the precise information about the volume of required liquid for administration for these forms of medications. The weaknesses of German package inserts in this aspect, as described above, could also be a European wide problem because many medicines have approval for different markets of the European Union member states. This means that the package inserts provide identical information in different languages, thus affecting a wider range of people.

In addition, no European guideline or directive recommends including details concerning the volume of liquid required for using orally taken, compact and shaped medicines in package inserts. The QRD template, available in the different languages of the European Union member states ${ }^{12}$, would be an appropriate location to include this information.

Furthermore, medical and pharmaceutical experts should also inform their patients of this recommendation when they sell or fill prescriptions for tablets or capsules. This should especially be done for medications that are known to harm the esophagus when their active substances are released in this organ. Nurses and other care givers should also be aware of this recommendation. If they give their patients a glass with a minimum $100 \mathrm{ml}$ liquid to take such medicines, it should help the patient avoid adverse drug reactions and increase therapeutic success.

\section{CONCLUSIONS}

A high percentage of patients swallow compact and shaped medicines, such as capsules and tablets, with too little liquid. It is recommended that every package insert of these medicine types should provide information about the precise required volume of liquid recommended to assure positive effects. In addition, medical and pharmaceutical experts, as well as any other caregivers, should provide this advice to their patients, or provide their patients with a sufficient amount of liquid to ensure the successful passage of tablets and capsules through the esophagus.

\section{CONFLICT OF INTEREST}

There is no conflict of interest. 


\section{References}

1. Sale J, Gignac M, Hawker G. How "bad" does the pain have to be? A qualitative study examining adherence to pain medication in older adults with osteoarthritis. Arthritis Care Res. 2006;55:272-278.

2. Gibbs S, Waters WE, George CF. The benefits of prescription information leaflets (1). Br J Clin Pharmacol. 1989;27:723739.

3. Fuchs J, Hippius M. Inappropriate dosage instructions in package inserts. Patient Educ Couns. 2007;67:157-168.

4. Kelloway JS, Kochevar JW, Sveum RJ, Hahn MA. Evaluation of the Autohaler Actuator: The effect of written patient instructions on correct use. J Asthma. 1993;30:373-379.

5. Quinzler R, Gasse C, Schneider A, Kaufmann-Kolle P, Szecsenyi J, Haefeli WE. The frequency of inappropriate tablet splitting in primary care. Eur J Clin Pharmacol. 2006;65:1065-1073.

6. Fuchs J, Finke A, Hippius M. Wie genau lassen sich Tabletten teilen? Internist Praxis. 2008;48:147-159.

7. Gallo SH, McClave SA, Makk LJK, Looney SW. Standardization of clinical criteria required for use of the 12.5 millimeter barium tablet in evaluating esophageal lumenal patency. Gastrointest Endosc. 1996;2:181-184.

8. Osmanoglou E; Van Der Voort IR; Fach K; Kosch O; Bach D; Hartmann V; Strenzke A; Weitschies W; Wiedenmann B; Trahms L; Mönnikes $\mathrm{H}$. Oesophageal transport of solid dosage forms depends on body position, swallowing volume and pharyngeal propulsion velocity. Neurogastroenterol Motil. 2004;16:547-556.

9. Jaspersen D. Drug-induced oesophageal disorders: pathogenesis, incidence, prevention and management. Drug Saf. 2000;22:237-249.

10. Fuchs J, Hippius M, Schaefer M. Analysis of German package inserts. Int J Clin Pharmacol Ther 2006;44:8-13.

11. Medizinische Medien Informations GmbH. Gelbe Liste Pharmaindex. http://www.gelbeliste.de/pharmindex/identa/suche/ (accessed June 26, 2009)

12. EMEA. QRD Template centralised procedure version 7.2 and MR/DC/referral procedures 1.2 . http://www.emea.europa.eu/htms/human/qrd/qrdtemplate.htm (accessed March 9, 2009) 